\title{
Research on Current Status of the Vegetation Contiguous to the Historic Sites in Trung Yen Commune, Son Duong District, Tuyen Quang Province
}

\author{
Do Cong Ba \\ Tan Trao University, Trung Mon, Yen Son, Tuyen Quang, Vietnam.
}

\begin{abstract}
How to cite this paper: Do Cong $\mathrm{Ba}$. (2021) Research on Current Status of the Vegetation Contiguous to the Historic Sites in Trung Yen Commune, Son Duong District, Tuyen Quang Province. International Journal of Food Science and Agriculture, 5(2), 278-284.

DOI: $10.26855 /$ ijfsa.2021.06.011
\end{abstract}

Received: March 25, 2021

Accepted: April 23, 2021

Published: May 13, 2021

*Corresponding author: Do Cong Ba, Tan Trao University, Trung Mon, Yen Son, Tuyen Quang, Vietnam.

Email: congbacdsp@gmail.com

\begin{abstract}
Research result on current status of the vegetation contiguous to the historic sites in Trung Yen commune, Yen Son district, Tuyen Quang province is classified and described into 7 sub-formations of 6 formations, including: (1) Tropical monsoon evergreen forest formation on lowland and mountains; (2) Tropical monsoon evergreen forest formation on limestone ground at low mountains; (3) Broadleaf evergreen woodland formation on lowland and mountains; (4) Tropical evergreen broadleaf shrub vegetation on feralit ground; (5) Low grass formation in form of tropical rice without any wooden trees; (6) Non-rice high grass formation including perennial herbaceous plants and ferns; In which, the tropical monsoon evergreen forest formation in lowland and low mountains has 2 sub-formations: (i) Evergreen broadleaf forest in lowland and low mountains that suffer light impact; (ii) Evergreen broadleaf forest in lowland and low mountains that suffer strong impact; Tropical monsoon evergreen forest formation on limestone ground at low mountains has 1 sub-formation: (iii) Evergreen broadleaf forest on limestone ground at low mountains suffering strong impact; Broadleaf evergreen woodland formation on lowland and mountains has 2 sub-formations: (iv) Evergreen broadleaf woodland forest in lowland behind mountainous fields, (v) Tropical bamboo forest on lowland and low mountains; Tropical evergreen broadleaf shrub vegetation on feralit ground has 1 sub-formation: (vi) Tropical evergreen shrub vegetation without scattered wooden trees; Non-rice high grass formation including perennial herbaceous plants and ferns has 1 sub-formation: (vii) Forest Banana vegetation.
\end{abstract}

\section{Keywords}

Vegetation, Current Status, Trung Yen, Son Duong, Tuyen Quang Province

\section{Introduction}

Trung Yen is a commune which locates in the North of Son Duong district, Tuyen Quang province. It is adjacent to Kim Quan commune, Yen Son district (YS) to the North, to Tan Trao commune, Son Duong district (SD) to the South, to Phu Dinh commune and Diem Maccommune (Dinh Hoa-Thai Nguyen) to the East, and to Minh Thanh commune (SD) and Cong Da commune (YS) to the West. The total natural land area of whole commune is 3,298.75 ha, of which: Agroforestry land accounts for 2,016.68 ha, agricultural land is 1,054.50 ha and other land is 227.57 ha. The commune has total of 07 villages with 1,238 households, 5,037 people and 04 ethnic groups, including: Tay; Nung; Dao; and Kinh. All people in all kinds of ethnic groups live together to make a living with main income from agriculture, forestry, hus- 
bandry and services. Through investigation, it is found that the plant resource here is relatively rich and diverse. However, the current status on exploitation of plant species gradually narrow the forest area, leading to risk that some rare plants may be disappeared in the next few years if we have no timely measures to protect forests.

\section{Research Objective and Method}

\subsection{Objective}

The research object is the vegetation in Trung Yen commune, Son Duong district, Tan Trao historic site (Tuyen Quang province). Research period lasts from 2018 to 2019.

\subsection{Research method}

\subsubsection{Inheritance method}

The paper collects and inherits selectively data, documents, reports related to the vegetation, flora of Tan Trao historic site from scientists, and authorities of Tuyen Quang province such as Department of Agriculture and Rural Development, People's Committees at all levels, Branch of Forest Protection Department and Management Board of Tan Trao Historic Site.

\subsubsection{Plant research method}

In the course of investigation, we utilize the route-based survey method and the standard plot method of Hoang Chung (2008) [1], Nguyen Nghia Thin (2007) [2].

* Route-based survey method

Based on the area map to identify the routes crossing each community, the first route is perpendicular to the main contour line, the next lines are parallel to the first line, the observation width is $2 \mathrm{~m}$ to each side for shrub vegetation or forest and $1 \mathrm{~m}$ to each side for grass vegetation. The distance between routes ranges from 50-100 $\mathrm{m}$ depending on topography and characteristics of vegetation for each community. The way of collecting data on route to be investigated is similar to that of standard plot method.

* Standard plot method

The determined standard plot position (OTC) represents and characterizes for each type of vegetation in terms of morphology, structure and topographic features (slope, exposure direction, etc.).

The OTC area is defined to be $400 \mathrm{~m}^{2}\left(20 \mathrm{~m} \mathrm{x} 20 \mathrm{~m}\right.$ ) for the forest vegetation, $16 \mathrm{~m}^{2}$ ( $4 \mathrm{~m} \mathrm{x} 4 \mathrm{~m}$ ) for the shrub vegetation and $1 \mathrm{~m}^{2}(1 \mathrm{~m} \mathrm{x} 1 \mathrm{~m})$ for the grass vegetation. For OTC in forest vegetation, 9 table-form plots (ODB) are made with area of $16 \mathrm{~m}^{2}(4 \mathrm{~m} \mathrm{x} 4 \mathrm{~m}$ ) for each plot and arranged at the corners of the OTC, on 2 diagonal lines and at the intersection of 2 diagonal of the OTC (the total area of the ODBs is at least 1/3 of the OTC area).

* The methods to determine types of vegetation

The types of vegetation in Tan Trao historic site are determined according to the classification framework of UNESCO (1973) [3]. Its structure is as follows:

I, II, etc. = Lớp quần hệ (Formation class)

A, B, etc. = Phân lớp quần hệ (Formation subclass)

1, 2, etc. = Nhóm quần hệ (Formation group)

a, b, etc. = Quần hệ (Formation)

(1), (2), etc. = Phân quần hệ (Subformation)

(a), (b), etc. = Các bậc nhỏ khác (Further subdivision)

\subsubsection{Methods of data analysis and processing}

Processing of plant sample: after being collected, the plant sample is processed, templated and preserved according to the method of Nguyen Nghia Thin (2007) [2].

Determine name of the plant species (scientific name, Vietnamese name) by comparising the morphology and collate with classification and description of species according to the following documents: Name of Vietnamese forest trees by the Ministry of Agriculture and Rural Development, 2000 [4]; Vietnamese Plants by Pham Hoang Ho, (1991-1993) [5], Categories of Vietnamese Plant Species $(2003,2005)$ by Nguyen Tien Ban et al. [6].

\section{Research Result}

\subsection{Current status of relics in the research area}

\subsubsection{National relics}

* The relic cluster of Nguyen Hue subdivision:

The relic cluster that locates in Ao Bu village, Trung Yen commune, Son Duong district was recognized as a national 
relic under Decision No. 53/2001/QD-BVHTT dated December 28, 2011.

Relic of Crude weapon forge: A place where officers of Nguyen Hue subdivision and people of Ao Cuc village opened a weapon forge to seize power in March 1945. The forge was in charge by comrade Tren The Mon supported by Mr. Dong and Ms. Thin. The forge mainly manufactured various types of swords, machetes, hackbuts and so on. After the weapons are completed, they would be distributed to the local self-defense forces used to seize and protect the revolutionary government.

Lan Khuan Trut: A place where the leadership of Nguyen Hue subdivision took place a meeting to prepare a plan of partial uprising as soon as possible in March 1945. Participants of the meeting consisted of comrades Song Hao, Chu Quy Luong, Hong Hai, Ta Xuan Thu, Dang Nguyen Minh, Khanh Phuong and households in Ao Cuc village. After this meeting, the comrades in the executive committee of the party directly arrived to appointed area to lead the revolution to seize power.

Relic of Ao Buc stone cave: A place used to hide weapons of the revolutionary army at the beginning of 1945 . On the night of the May $12^{\text {th }}$ and the morning of May $13^{\text {th }}, 1945$, the armed units and masses of people proceeded to attack and liberate Dang Chau post (Son Duong county seat) completely on March 16, 1945. All weapons, military equipment and tools obtained from enemies were transported to stone cave of Ao Buc village for storage. The person in charge of looking after this armory were two comrades named Dang Van Dong and Ly Van Phong.

Relic of Lan Ngoi Can: A place where the revolutionary comrades used to engrave the seal and print the revolutionary documents in the pre-uprising period in 1945. After March 10,1945, a series of communes such as Trung Yen, Minh Khai, Tan Trao, etc. seized power to the people. Communal and district governments were established everywhere. For management affairs of the government, the executive committee of the party of Nguyen Hue Subdivision B has assigned the printshop to engrave seals for the government. The comrade who took responsibility for this mission was Tran The Mon. Each commune would be engraved a seal of "Viet Minh commune front".

* Trung Yen relic cluster:

This relic cluster locates in Dong Ma village, Trung Yen commune, Son Duong district and was recognized as a national relic under Decision No. 06/2000/QD-BVHTT dated April 13, 2000.

The relic of tent and safe tunnel of President Ton Duc Thang: A place where comrade Ton Duc Thang was used to live and work from the end of 1952 to August 1954.

Relic of the Standing Committee of the National Assembly: A place where the Standing Committee of the National Assembly was to live and work from late 1952 to August 1954.

Lien Viet Front Relic: A place where Lien Viet Front was used to live and work from late 1952 to August 1954.

* Vietnam news agency: This relic locates in Hoang Lau village, Trung Yen commune, Son Duong district, and was recognized as a national relic under Decision No. 53/2001/QD-BVHTT dated December 28, 2001. This was the news center of the Party Central Committee and the Government.

* Ministry of Home Affairs: This relic locates in Yen Thuong village, Trung Yen commune, Son Duong district, and was recognized as a national relic under the regulation No. 71/2004/QD-BVHTT dated August 23, 2004. This was the place where the Ministry of Home Affairs moved to work.

\subsubsection{Provincial Relics}

* Place of swearing: The relic locates in Ao Cuc village, Trung Yen commune, Son Duong district, and was granted a certificate of provincial relic in 2006. This was the place where the people of Ao Cuc village held a ceremony to swear to join the revolution in 1942.

* Ban Ngoi Nho Relic: The relic locates in Hoang Lau village, Trung Yen commune, Son Duong district, and was granted a certificate of provincial relic in 2006. This was the place where comrades of National Salvation Army II built revolutionary facility in the period of 1941-1945.

* Relic of Mr. Trieu Van Hien's house: The relic locates in Trung Yen commune, Son Duong district, and was granted a certificate of provincial relic in 2006. This was the place where President Ho Chi Minh was used to live and work from November 27 to December 4, 1974.

* Relic of Yen Thuong stone cave: Yen Thuong Stone Cave is a natural stone cave in the Thoi mountains, Yen Thuong village, Trung Yen commune where gold and silver of the Central was hidden in 1947.

National relics are invested in embellishment and strict protection, so their adjacent vegetation almost remains the original state, even the parts that were exhaustedly exploited previously are also in the process of gradual recovery. Provincial relics have not paid adequate attention, so the vegetation contiguous to those recovers very slowly, some areas are almost impossible to be back as they were.

\subsection{Natural vegetation}

Through classification framework of UNESCO (1973) applied by Phan Ke Loc to Vietnam (1985) for investigating 
the current status of the vegetation contiguous to the relic sites in Trung Yen commune, Yen Son district, Tuyen Quang province [7], we have identified 7 sub-formations, 6 formations belonging to 5 groups, 5 sub-classes of 4 formations, as presented in Table 1 below.

Table 1. System of vegetation contiguous to the relic sites in Trung Yen commune, Son Duong district, Tuyen Quang province

\begin{tabular}{|c|c|}
\hline No. & Vegetation \\
\hline I. & Enclosed forest formation \\
\hline I.A & Enclosed evergreen forest formation class \\
\hline I.A.2 & Group of tropical and sub-tropical evergreen forest formations \\
\hline I.A.2a & Tropical monsoon evergreen forest formation on lowland and mountains \\
\hline I.A.2a(1) & Evergreen broadleaf forest sub-formation in lowland and low mountains that suffer light impact \\
\hline I.A.2a(2) & Evergreen broadleaf forest sub-formation in lowland and low mountains that suffer strong impact \\
\hline I.A.2e & Tropical monsoon evergreen forest formation on limestone ground at low mountains \\
\hline I.A.2e(1) & Evergreen broadleaf forest sub-formation on limestone ground at low mountains suffering strong impact \\
\hline II. & Woodland formation \\
\hline II.A. & Mainly evergreen woodland formation subclass \\
\hline II.A.1 & Group of evergreen broadleaf woodland formation \\
\hline II.A.1a & Broadleaf evergreen woodland formation on lowland and mountains \\
\hline II.A.1a(1) & Evergreen broadleaf woodland forest sub-formation in lowland behind mountainous fields \\
\hline II.A.1a(2) & Tropical bamboo forest sub-formation on lowland and low mountains \\
\hline III. & Shrub vegetation formation \\
\hline III.A. & Mainly evergreen shrub formation subclass \\
\hline III.A.1 & Group of evergreen broadleaf shrub vegetation formations \\
\hline III.A.1f & Tropical evergreen broadleaf shrub vegetation formation on feralit ground \\
\hline III.A.1f(2) & Tropical evergreen shrub vegetation sub-formation without scattered wooden trees \\
\hline V. & Grass formation \\
\hline V.C & Low grass formation in form of rice \\
\hline V.C.2 & Group of low grass formations in form of tropical rice without any wooden trees \\
\hline V.C.2a & Low grass formation in form of tropical rice without any wooden trees \\
\hline V.D. & Non-rice grass formation \\
\hline V.D.1 & Group of non-rice high grass formations \\
\hline V.D.1a & Non-rice high grass formation including perennial herbaceous plants and ferns \\
\hline V.D.1a(1) & Forest Banana Sub-formation \\
\hline
\end{tabular}

From the results in Table 1, characteristics on morphology and structure of the formation and sub-formation in Trung Yen commune, Son Duong district, Tuyen Quang province are described as follows:

* I.A.2a. Tropical monsoon evergreen forest formation on lowland and mountains

This formation consists of 2 sub-formations:

- I.A.2a(1). Evergreen broadleaf forest sub-formation in lowland and low mountains that suffer light impact:

This forest type has a 5-layer structure with 3 distinct layers of wooden trees:

Emergent layer (A1) includes species such as:Đinh (Markhamia stipulata), Chò chỉ (Parashorea chinensis), Trám trắng (Canarium album), Táu lá nhỏ (Vatica ordorata), Trám đen (Canarium tramdenum), Xoan nhừ (Choerospondias axillaris)... This layer has an average height of $20-25 \mathrm{~m}$, an average diameter of $30-35 \mathrm{~cm}$ with irregular canopy and a coverage of about $15 \%-20 \%$.

Canopy layer (A2) includes species such as: Chẹo tía (Engelhardtia roburghiana), Dẻ gai (Castanopsis armata), Giổi lông (Michelia balansae), Trám trắng (Canarium album), Gội núi (Aglaia perviridis)..., there are many species merged to form a fairly continuous canopy layer with average height of $15-20 \mathrm{~m}$, diameter of $15-25 \mathrm{~cm}$ and coverage of about $35 \%-45 \%$. 
Understory layer (A3) includes species such as: Nhãn rừng (Nephelium cuspidatum), Sảng (Sterculia lanceolata), Đu đủ rừng (Trevesia palmata), Ràng ràng (Ormosia balanse), Cà ồi (Castanopsis tesselata)... including mainly wooden trees with a height of 6-9 m, a diameter of $15-25 \mathrm{~cm}$ and a coverage of $30 \%$.

Shrub layer (B) has plant composition that is mainly species of the Na family (Anononaceae), họ Đơn nem (Myrsinaceae), họ Cam quýt (Rutaceae)...

Forest floor (C) consists of species of Thông đất (Lycopodiaceae), họ Ráy (Araceae), họ Hoà thảo (Poaceae),... The coverage is about $20 \%-25 \%$.

Other vegetation includes species of vines that are relatively rich such as:Mây bắc bộ (Calamus tonkinensis), Hoa giẻ thơm (Desmos pedunculosus)..., typical epiphyte species such as:Cốt toái bổ (Drynariafortunei), Tổ điểu (Asplenium nidus)...

Although some valuable wooden trees in this sub-type of forest have been exploited, it basically retains its primitive nature as it was. This sub-type of forest is often far from residential areas, at an altitude of 300-700 m, mainly distributed on ground mountains, and some located in rock mountains.

- I.A.2a(2). Evergreen broadleaf forest sub-formation in lowland and low mountains that suffer strong impact:

This subtype of forest has a normal structure, with an unclear emergent layer A1.

Canopy layer (A2): This layer includes species such as: Kháo vàng (Machilus bonii), Ràng ràng mít (Ormosia balansae), Côm tầng (Elaeocarpus griffithii), Vàng anh (Saraca dives)..., these species have an average height of 10-15 $\mathrm{m}$, average diameter of $15-20 \mathrm{~cm}$ and a coverage of $50 \%$.

Understory layer (A3): This layer includes species such as: Móng bò (Bauhinia championii), Màng tang (Litsea cubeba), Máu chó lá nhỏ (Knema globularia),... the species in this layer are small wooden trees with an average height of 5-8 $\mathrm{m}$, an average diameter of $10-15 \mathrm{~cm}$ and a coverage of $40 \%$.

Shrub layer (B): This layer includes shrubs such as: Thóc lép (Desmodium gangeticum), Bọt ếch (Glochidion eriocarpum), Ruối (Streblus asper)... the species in this layer have an average height of 2-4 m, and a coverage of $25 \%$.

Forest layer (C): This layer includes species such as: Sa nhân (Amomum longiligulare), Ráy (Alocasia macrorrhiza), Cỏ rác (Microstegium vagans)... with a coverage of 30\%-40\%.

Other species: include a number of vines: Hà thủ ô trắng (Streptocaulon griffithii), Dưa dại (Zehneria indica), Đại hái (Hodginsonia macrocarpa), ...

This sub-type of forest is very popular with a large area distributed near residential areas at altitude below $300 \mathrm{~m}$. Due to strong impact from exploitation to take rare and valuable wooden trees, so only low quality trees remain.

* I.A.2e. Tropical monsoon evergreen forest formation on limestone ground at low mountains

- I.A.2e(1). Evergreen broadleaf forest sub-formation on limestone ground at low mountains suffering strong impact:

Due to overexploitation, this sub-type of forest has very few valuable large trees. The structure of the forest often does not present emergent layer A1 clearly.

Canopy layer (A2): This layer includes species such as: Thị rừng (Diospiros sp.), Trai lý (Garciniafagraeoides), Mạy tèo (Streblus macrophyllus)... with an average height of $10-20 \mathrm{~m}$, average diameter of $15-25 \mathrm{~cm}$, and canopy coverage of 0.5-0.8.

Shrub layer (B): This layer includes species such as: Lấu đỏ (Psychotria rubra), Găng trâu (Randia spinosa), Đơn nem (Maesa perlarius)... with an average height of 2-5 m, and canopy coverage of 0.3-0.5.

Forest layer (C): Plant composition is poor with some species such as: Thông đất (Lycopodium cernum), Cỏ rác (Microstegium vagans), Cỏ lá tre (Centotheca lappacea)...

Other species: include a number of vines: Dưa dại (Zehneria indica), Sắn dây rừng (Pueraria montana), Móc mèo (Caesalpinia bonduc)...

* II.A.1a. Broadleaf evergreen woodland formation on lowland and mountains

- II.A.1a(1). Evergreen broadleaf woodland forest sub-formation in lowland behind mountainous fields:

This sub-type of forest is mainly distributed near residential areas with plant composition of bright-growing, fast-growing pioneering trees. It has a 3-layer structure:

Wooden tree layer: The canopy coverage is 0.4-0.5; common height ranging from 5-10 m includingfollowing species: Đu đủ rừng (Trevesia palmata) Mán đỉa (Pithecollobium lucidum), Ba soi (Macaranga denticulata), Me rừng (Phyllanthus emblica), Lòng mang xanh (Pterospermunheterophyllum), Hoắc quang (Wendlandia paniculata)...

Shrub layer: includes species such as: Ba bét trắng (Mallotus apenta), Đơn đỏ (Excoecaria cochinchinensis), Sói rừng (Alchornea tiliifolia), Đom đóm lá đay (Alchornea tiliifolia), Lấu núi (Psychotria montana), Đơn đỏ (Ixora coccinea)...

Forest layer: includes mainly species of Hòa thảo (Poaceae), Cói (Cyperaceae), Cúc (Asteraceae). Some typical examples are: Cói túi ấn (Carex indica), Cỏ lau (Saccharum officinarum), Cỏ tranh (Imperata cylindrica)...

Other species: include a number of typical vines of họ Đậu (Fabaceae), họ Nho (Vitaceae), họ Bòng bong (Schizaeaceae)...

- II.A.1a(2). Tropical bamboo forest sub-formation on lowland and low mountains: 
Data in Table 2 shows that the area of bamboo forest is very large.

Table2. Area of bamboo forest in the vegetation contiguous to relics of Trung Yen commune, Son Duong district, Tuyen Quang province

\begin{tabular}{cccccc}
\hline \multirow{2}{*}{ No. } & \multirow{2}{*}{ Commune } & \multicolumn{2}{c}{ Natural forest (ha) } & \multicolumn{2}{c}{ Planted forest (ha) } \\
One-type bamboo forest & Planted bamboo forest & Total(ha) \\
\hline 1 & Trung Yên & 725.66 & 105.58 & 2.66 & 833.90 \\
\hline
\end{tabular}

Source: Tuyen Quang Department of Agriculture and Rural Development, 2018 [8].

The investigation results indicate that bamboo forest is formed through overexploitation or burning of forests for burnt-over land. Depending on the level of broadleaf trees, it will be a(an) one-type or mixed forest.

+One-type bamboo forest: Formed after overexploitation or forest burning for burnt-over land, is characterized by rừng Nứa (Neohouzeana dulloa), with an average height of 6-8 m, average diameter of 3-5 cm, and coverage of 80\%-90\%. There is only a few species of plants are found below Neohouzeana dulloa canopy of such as: Mía dò (Costus speciosus), Chặc chìu (Tetracera scandens), Trung quân (Ancistrocladus scandens)...

+Bamboo forest mixed with broadleaf trees: In this type of forest, in addition to the main layer dominated by Cork trees with height of 6-8 m, it has a wooden tree layer with height of 10-20 m, canopy coverage of 0.2-0.4. Some species of wooden trees are: Côm tầng (Elaeocarpus griffithii), Mý (Lysidice rhodostegia), Chẹo tía (Engelhardtia roburghiana), Ràng ràng (Ormosia balansae)...

The plant composition of shrub and forest layer prefer shade more than One-type bamboo forest.

* III.A.1f.Tropical evergreen broadleaf shrub vegetation formation on feralit ground

- III.A.1f(2). Tropical evergreen shrub vegetation sub-formation without scattered wooden trees:

This sub-type consists of communities such ascỏ Lào (Eupatorium odoratum) cây Mua (Melastoma candidum), quần xã cỏ Lá tre (Centotheca lappacea)..., grown into small regions scattered in the area with a large number of individuals. These shrub formaitons are formed mainly when burnt-over lands are newly uninhibited or overgrazed after abandonment.

* V.C.2a. Low grass formation in form of tropical rice without any wooden trees

This formation is relatively popular, formed after culture of burnt-over land, distributed into small scattered regions, a place for frequent grazing with degraded land. The main plant composition is some species of grasses, herbaceous plants, shrubs and vines such as: Cỏ gà (Cynodondactylon), Cỏ may (Chrysopogon aciculatus), Cỏ gấu (Cyperus rotundus), Cứt lợn (Ageratumconyzoides)...

* V.D.1a. Non-rice high grass formation including perennial herbaceous plants and ferns

- V.D.1a(1). Forest banana sub-formation:

Under the canopy of forest banana, there are some species of grasses, ferns, and vines belonging to họ Hòa thảo (Poaceae), Cúc (Asteraceae), Bòng bong (Schizeaceae)..., with overall coverage of 80\%.

\subsection{Crops formation}

The crops vegetation contiguos to the relic sites includes mainly wet rice, corn and other crops with an area of 141.77 ha. The area of planted forest in the relic is 636.57 ha, mainly one-type planted forest under the project 661 funded by the Government, including the following forest types: Keo tai tượng (Acacia mangium), Keo lai hom (A. hybrid). Các loại rừng trồng khác như rừng Mỡ (Manglietia conifera), rừng Trám (Canarium album), rừng Xoan (Melia azedarach), Sấu (Dracontomelon dupereanum), Tre (Bambusa ssp), Mai (Dendrocalamus giganteus) with a small area planted scatteredly in residential land, forest garden, etc.; In addition, fruit trees such as Orange, Mango, Plum, Litchi, Longan and so on are planted in gardens, forest gardens or farms.

The research result shows that types of vegetation contiguous to the historical sites in Trung Yen commune, Son Duong district, Tuyen Quang province are quite rich and diverse, which plays a very important role in both creating harmonious and natural landscape value for the relics for sightseeing, ecotourism and contributing to value of environmental protection, biodiversity, relics protection and livelihoods of the people.

\section{Conclusion}

The investigation result for the vegetation contiguous to the historical sites indicates that the nationally-recognized relics suffer less impact for plant composition and structure of the natural forest with 5 layers, of which there are 3 distinct wooden tree layers: emergent layer, canopy layer, understory layer, shrub layer, forest layer. The bamboo forests in the research area are all formed from the enclosed tropical evergreen forest in the lowland and low mountains. One-type forest and mixed forest with broadleaf trees mainly distributes in many villages and communes, etc. It also shows that due to lack of attention, the exploitation of forest resource in the vegetation adjacent to the provin- 
cial-recognized relics reduced the diversity of forest species, thereby degrading environmental protection capaicty as well as the function of creating landscape for the relics.

\section{Acknowledgement}

This research is funded by Tan Trao University in Tuyen Quang, Vietnam.

\section{References}

[1] Hoang Chung. (2008). Methods to research plant communities. Education Publishing House, Hanoi.

[2] Nguyen Nghia Thin. (2007). Plant research methods. Publishing House of VNU, Hanoi.

[3] UNESCO. (1973). International classification and mapping of vegetation. Paris.

[4] Ministry of Agriculture and Rural Development. (2000). Name of Vietnamese Forest Trees. Publishing House of Agriculture, Hanoi.

[5] Pham Hoang Ho. (1991-1993). Vietnamese plants. volume I-III, Motreal, Canada.

[6] Nguyen Tien Ban, et al. (2003, 2005). List of plant species in Vietnam. Publishing House of Agriculture, Hanoi.

[7] Phan Ke Loc. (1985). "Trial application of the UNESCO classification framework to build a classification framework for forest vegetation in Vietnam”. Journal of Biology, (12), pp. 27-29.

[8] Department of Agriculture and Rural Development. (2018). Report No. 392/BC-SNN dated October 17, 2018 on the implementation results of Forestry affairs plan 2018. Tuyen Quang.

[9] Tran Dinh Ly, et al. (2018). Vegetation ecology. Publishing House of Natural Science and Technology, Ha Noi.

[10] Ministry of Agriculture and Rural Development. (2019). Decision No. 991 / QD-TTg on announcing the current state of national forests in 2018. Ha Noi.

[11] Vo Thanh Son. (2016). Biodiversity Conservation and Sustainable Development in the world and in Vietnam-from Theory to Practice. Publishing House of Science and Technology, Ha Noi.

[12] Dang Quoc Vu. (2016). Research on the plant diversity as a basis for conservation in Xuan Lien Natural Reserve, Thanh Hoa Province, Viet Nam. Doctor of Biology Thesis, Institute of Ecology and Biological Resources, Ha Noi.

[13] Decision No. 2073 / QD-TTg dated December 22, 2017 of the Prime Minister on Approving the Master Plan for Development of Tan Trao National Tourism Area, Tuyen Quang Province up to 2030.

[14] Vu Thi Thanh Huong. (2017). Research on the characteristics of degraded vegetation and plantation forest models in Cam Pha City, Quang Ninh Province, Viet Nam. Doctor of Biology Thesis, Thai Nguyen University of Education, Thai Nguyen University.

[15] Nguyen Thi Hai, Tran Huy Thai, Nguyen The Cuong, Tran Thi Thanh Van. (2017). Diversity of medicinal plants in Na Hang Natural Reserve, Tuyen Quang Province, Viet Nam. Scientific Journal of Tan Trao University, Vol. 3, No. 6, September 2017. Pp. 45-50. 